\title{
Salivary Characteristics in Children Aged 2 Years Old And Under with Severe Early Childhood Caries (SECC)
}

\author{
Ameta Primasari \\ Department of Oral Biology \\ Faculty of Dentistry, Universitas Sumatera Utara \\ Medan, Indonesia \\ ametaprima@yahoo.com \\ Nevi Yanti \\ Department of Conservative Dentistry \\ Faculty of Dentistry, Universitas Sumatera Utara \\ Medan, Indonesia
}

\author{
Essie Octiara \\ Department of Pediatric Dentistry \\ Faculty of Dentistry, Universitas Sumatera Utara \\ Medan, Indonesia
}

\section{Muhammad Isra Reskitama}

Student

Faculty of Dentistry, Universitas Sumatera Utara

Medan, Indonesia

\begin{abstract}
Severe Early Childhood Caries (SECC) is progressive tooth decay with multifactorial etiology, which one of them is saliva. Salivary flow, pH, salivary buffer capacity are critical factors for developmental regulation and regression of the caries process. It is mandatory to comprehend the salivary characteristics possessed by children with SECC to perform prevention programs, given that the high prevalence of SECC in many countries. The objectives of this study were to investigate the salivary characteristics (flow rate, $\mathrm{pH}$ and salivary buffer) in children aged 2 years old and under that suffered from SECC and children with caries-free. This research was an observational analytic research with cross sectional design. Sample size was 30 children with SECC and 30 children with caries-free as control group. Sampling was done using purposive sampling method, with age criteria 2 years old and under and good general conditions. Examination of unstimulated salivary characteristics such as salivary flow rate, $\mathrm{pH}$ and buffer capacity was done using GC saliva check, with unpaired t-test used for analysis. Results showed that mean salivary flow rate in children with SECC was lower than in caries-free children, mean salivary $\mathbf{p H}$ in SECC children was also lower in SECC children compared with caries-free children, and the buffer capacity was also lower in SECC children rather than in control group. As conclusion, salivary characteristics of SECC children had lower quantity and quality rather than caries-free children.
\end{abstract}

Keywords-SECC, saliva, flow rate, $\mathrm{pH}$, buffer

\section{INTRODUCTION}

Early Childhood Caries (ECC) is a pattern of carious lesion that occurs in infants, toddlers and preschool children aged 71 months years and under. Severe Early Childhood Caries (SECC), is a more progressive caries form than ECC. Children under 3 years old are said to be suffering from SECC if there is a caries (lesion or cavity) that occurs in at least one smooth surface of teeth [1].
Dental caries in children is still a quite alarming problems in various countries in the world. Research showed that the prevalence of SECC varied from 9.5\% in Germany [2]. 24.7\% in Manitoba (Canada) [3], and $2.7 \%$ with average $\mathrm{dmft}$ score 6.86 in Southern Italia [4]. SECC prevalence is higher in developing countries rather than in developed countries. The researches in India showed that the prevalence of SECC varied between 21\% [5]-35.1\% [6], while in Northern Thailand the prevalence was higher by $44.1 \%$ [7]. Prevalence of SECC in Indonesia is also quite high, in Surabaya $29.2 \%$ [8], while in Medan, the prevalence in 3 years old children and under was $16 \%$ [9].

The high prevalence of SECC in early childhood has become, a dentist's concern. Therefore, dentist needs to know the risk factors of caries in early childhood. Saliva is one of the factors that play a role in the process of dental caries, but saliva has a unique role because it can also act to prevent caries [10]. The knowledge of saliva as one of the risk factors of caries especially in children with high caries risk can aid/assist dentist in performing prevention therapy and improve dental care to be more effective.

Saliva can maintain oral hygiene by acting as a protective layer against food debris (lubrication), antibacterial activities, $\mathrm{pH}$ (6-7) [11], buffers against acid formation, flow related clearance of diet, and salivary viscosity [12]. Salivary flow rate, $\mathrm{pH}$, buffer, and remineralization capacity of saliva are critical factors in developmental regulation and regression of the caries process. If the environment supports, saliva will contribute to strengthening the teeth by building strong apatite structure. Conversely, if the environment is unfavorable, salivary flow can help remove and perform buffer from the acid that forms in the teeth. Unstimulated salivary flow lower than $0.3 \mathrm{ml} / \mathrm{min}$ is a risk factors for caries [13]. 
Research on 25 SECC children and 25 caries-free children aged 3-5 years old showed that unstimulated salivary $\mathrm{pH}$ in caries-free group was higher than in SECC children $(\mathrm{p}<0.0001)$. Salivary $\mathrm{pH}$ had a negative correlation between two groups $(r=-0.47, p<0.05)$, which means that the more severe the caries is, the lower the child salivary $\mathrm{pH}$ [12]. Buffer capacity of SECC children is also lower than in control groups [14], as well as the mean salivary flow rate [15]. Different results obtained by Almushyt (2010) showed that there were no difference between the salivary flow rate and buffer capacity between SECC and caries-free children [16].

Further research is needed because of the different results in the research on $\mathrm{pH}$, buffer capacity, and salivary flow rate between SECC and caries-free children. Besides that, salivary characteristic in children aged 2 years old or under is also not widely published. The purpose of this study was to determine the salivary characteristic (flow rate, $\mathrm{pH}$, and salivary buffer) in children aged 2 years old and under that suffered from SECC and caries-free children.

\section{MATERIALS AND METHODS}

This research was an observational analytic research with cross sectional design. Population of this research were children who came to the Integrated Service Post in Medan Selayang district. Sampling was done using purposive sampling method, with the sample criteria were children aged 2 years old and under, good general condition, didn't consume any medicine in the near future, and willingly to participate in the study by filling the informed consent. Sample size were 30 children that suffered from SECC and 30 caries-free children as control group. SECC category is based on American Association of Pediatric Dentistry (AAPD) criteria which is a caries in smooth surface of the tooth. Salivary characteristic examination such as salivary flow rate, $\mathrm{pH}$, and buffer capacity was done using GC saliva check. Unstimulated saliva was taken at 9 to 11 o'clock GMT+7 hours, and children didn't consume any food or drinks 1 hour before saliva is taken. Salivary flow rate criteria is divided into 2 which was normal salivary flow rate $(\geq 0.3 \mathrm{ml} / \mathrm{min})$ and abnormal salivary flow rate $(<0.3 \mathrm{ml} / \mathrm{min})$. Buffer capacity is categorized with normal (10-12), low (6-9), and very low (0-5), salivary $\mathrm{pH}$ is divided into normal (6.8-7.8), acidic (6-6.6), and very acidic (5-5.8). Data analysis was tested with chi-square for categorical data and unpaired t-test for numerical data. Ethical clearance was obtained from the Research Ethics Committees of Faculty of Medicine, University of Sumatera Utara.

\section{RESULTS}

The age range of subjects in this research was 8 to 24 months. The mean caries experience in children suffered from SECC was $2.73 \pm 1.53$. Based on the salivary flow rate, there were 4 children (13.3\%) suffered from SECC had abnormal salivary flow rate $(<$ $0.3 \mathrm{ml} / \mathrm{min}$ ), whereas all of the children in control group had normal salivary flow rate ( $\geq 0.3 \mathrm{ml} / \mathrm{min})$. There was a significant difference in salivary flow rate between children with SECC and caries-free children $(p<0.001)$ (Table I).

TABLE I. DIFFERENT CATEGORIES OF SALIVARY FLOW RATE BETWEEN SECC AND CARIES-FREE CHILDREN

\begin{tabular}{|c|c|c|c|c|c|c|c|}
\hline \multirow{3}{*}{ Group } & \multicolumn{7}{|c|}{ Salivary Flow Rate } \\
\hline & \multicolumn{2}{|c|}{ Abnormal } & \multicolumn{2}{|c|}{ Normal } & \multicolumn{2}{|c|}{ Total } & \multirow{2}{*}{$\mathbf{P}$} \\
\hline & $\mathbf{n}$ & $\%$ & n & $\%$ & $\mathbf{n}$ & $\%$ & \\
\hline SECC & 4 & 13.3 & 26 & 86.7 & 30 & 100 & \multirow[b]{2}{*}{$<0.001^{\mathrm{a}}$} \\
\hline $\begin{array}{l}\text { Caries- } \\
\text { free }\end{array}$ & 0 & 0 & 30 & 100 & 30 & 100 & \\
\hline
\end{tabular}

Based on salivary buffer capacity in children with SECC, most of the children, 22 children $(73.3 \%)$ had very low buffer capacity, followed by 8 children (26.7\%) with low buffer capacity and there were no children who had normal buffer capacity. In caries-free children, there were 14 children $(46.7 \%)$ had normal salivary buffer capacity, 16 children $(53.3 \%)$ with low buffer capacity and there were no children who had very low buffer capacity. Statistic results showed that there were no difference in salivary buffer between SECC and caries-free children $(\mathrm{p}<0.001)$ (Table II).

TABLE II. DIFFERENT CATEGORY OF SALIVARY BUFFER BETWEEN SECC AND CARIES-FREE CHILDREN.

\begin{tabular}{|c|c|c|c|c|c|c|c|c|c|}
\hline \multirow{3}{*}{ Group } & \multicolumn{8}{|c|}{ Salivary Buffer } \\
\cline { 2 - 11 } & \multicolumn{2}{|c|}{ Very low } & \multicolumn{2}{|c|}{ Low } & \multicolumn{2}{c|}{ Normal } & \multicolumn{2}{c|}{ Total } & p \\
\cline { 2 - 11 } & $\mathbf{n}$ & $\mathbf{\%}$ & $\mathbf{n}$ & $\mathbf{\%}$ & $\mathbf{N}$ & $\mathbf{\%}$ & $\mathbf{n}$ & $\mathbf{\%}$ & \\
\hline SECC & 22 & 73.3 & 8 & 26.7 & 0 & 0 & 30 & 100 & $<0.001^{\mathrm{b}}$ \\
\hline $\begin{array}{c}\text { Caries- } \\
\text { free }\end{array}$ & 0 & 0 & 16 & 53.3 & 14 & 46.7 & 30 & 100 & \\
\hline
\end{tabular}

In children with SECC, most of the salivary $\mathrm{pH}$ was very acidic (17 children, 56.7\%) and acidic (12 children, $40 \%$ ) and only 1 children had normal salivary $\mathrm{pH}$, whereas in caries-free children, most of the salivary pH was normal (26 children, $86.7 \%$ ), only a few had acidic salivary $\mathrm{pH}$ (4 children, $13.3 \%$ ), and there were no children with very acidic salivary $\mathrm{pH}$. Based on the statistical test, there were difference in salivary $\mathrm{pH}$ between SECC and caries-free children ( $p<0.001)$ (Table III).

TABLE III. DIFFERENT CATEGORY OF SALIVARY PH BETWEEN SECC AND CARIES-FREE CHILDREN.

\begin{tabular}{|c|c|c|c|c|c|c|c|c|c|}
\hline \multirow{3}{*}{ Group } & \multicolumn{9}{|c|}{ Salivary pH } \\
\hline & \multicolumn{2}{|c|}{$\begin{array}{c}\text { Very } \\
\text { acidic }\end{array}$} & \multicolumn{2}{|c|}{ Acidic } & \multicolumn{2}{|c|}{ Normal } & \multicolumn{2}{|c|}{ Total } & \multirow[t]{2}{*}{$\mathbf{p}$} \\
\hline & $\mathbf{n}$ & $\%$ & $\mathbf{n}$ & $\%$ & $\mathbf{n}$ & $\%$ & $\mathbf{n}$ & $\%$ & \\
\hline SECC & 17 & 56.7 & 12 & 40 & 1 & 3.3 & 30 & 100 & $<0.001^{\mathrm{c}}$ \\
\hline $\begin{array}{l}\text { Caries- } \\
\text { free }\end{array}$ & 0 & 0 & 4 & 13.3 & 26 & 86.7 & 30 & 100 & \\
\hline
\end{tabular}

Results showed that the mean salivary flow rate in caries-free children was higher than in SECC children, which was $0.80 \pm 0.21$ versus $0.37 \pm 0.12$ and this difference was statistically significant. Similarly, the mean of salivary $\mathrm{pH}$ and salivary buffer were higher in the caries-free group compared with SECC children, 
and this difference was statistically significant ( $p$ $<0.001$ ) (Table IV).

TABLE IV. DIFFERENT SALIVARY CHARACTERISTIC IN SECC AND CARIES-FREE CHILDREN.

\begin{tabular}{|c|c|c|c|}
\hline $\begin{array}{c}\text { Salivary } \\
\text { characteristic }\end{array}$ & SECC & Caries-free & P \\
\hline Flow rate $(\mathrm{ml} / \mathrm{min})$ & $0,37 \pm 0,12$ & $0.80 \pm 0.21$ & $<0.001^{\mathrm{d}}$ \\
\hline Salivary pH & $5,86 \pm 0,51$ & $7.02 \pm 0.39$ & $<0.001^{\mathrm{d}}$ \\
\hline Buffer Saliva & $4,93 \pm 1,38$ & $9.30 \pm 1.23$ & $<0.001^{\mathrm{d}}$ \\
\hline
\end{tabular}

\section{DISCUSSION}

Saliva is very important to maintain oral health. Salivary flow rate is an independent factor that will affect other salivary defense factors. $\mathrm{pH}$ and buffer capacity are dependent variables on salivary flow rate [12].

Results of this study showed that the mean salivary flow rate in SECC children was lower $(0.37 \pm 0.12$ $\mathrm{ml} / \mathrm{min})$ than caries-free children $(0.80 \pm 0.21 \mathrm{ml} / \mathrm{min})$ $(\mathrm{p}<0.001)$. This results were in accordance with Animireddy et al. research in 2014 which stated that the mean of salivary flow rate in SECC children is lower than in caries-free children [15].

It had been shown in this research that reduction in salivary flow may lead to an increasing of dental caries lesion in SECC children. Normal unstimulated salivary flow ( $\geq 0.3 \mathrm{ml} / \mathrm{min}$ ) is expected to eliminate and neutralize the harmful effect on oral health such as bacteria that causing caries, low $\mathrm{pH}$ and food debris that attached to the tooth and oral cavity. However, if unstimulated salivary flow less than $0.3 \mathrm{ml} / \mathrm{min}$, then it was a risk factors that causing caries [13]. This results were in accordance with study which stated that low salivary flow rate $(<0.3 \mathrm{ml} / \mathrm{min})$ was found in $13.3 \%$ SECC children, while in caries-free, all of the children had normal salivary flow rate $(\mathrm{p}<0.001)$.

The mean of unstimulated salivary buffer was also lower in SECC children $(4.93 \pm 1.38)$ rather than in caries-free children $(9.30 \pm 1.23) \quad(\mathrm{p}<0.0001)$. This results were in accordance with Kuriakose et al (2013) which stated that buffer capacities in SECC children was lower than in caries-free children [14].

Salivary buffer capacity can protect tooth from caries, lower salivary buffer capacity can cause disturbance or failure to neutralize plaque acid and reduced remineralization in early enamel lesion [17]. Salivary buffer ability depends on phosphate system, carbonate acid, and bicarbonate system. Carbonatebicarbonate acid system is the most important buffer system in stimulated saliva, while in unstimulated saliva, the one that plays the role is phosphate [8].

In this research, the salivary buffer in most of SECC children was very low (73.3\%), followed by low buffer capacity $(26.7 \%)$ and there were no children with normal buffer capacity; while in caries-free children, most of them $(53.3 \%)$ had low buffer capacity, $46.7 \%$ had normal buffer capacity and none of them had very low buffer capacity $(\mathrm{p}<0.001)$ (Table II). Because most of SECC children had low buffer capacity $(73.3 \%)$, this will affect their saliva ability in maintaining oral hygiene.

Buffer capacity is related with salivary flow and salivary $\mathrm{pH}$, the lower the salivary flow, the buffer capacity will also be lower, and vice versa [12]. This is proven in this research that the salivary flow rate in SECC children was lower than in caries-free children, and this will affect the buffer capacity in SECC children with the presence of lower salivary buffer in SECC children than in caries-free children. Buffer capacity act as plaque $\mathrm{pH}$ regulator and neutralize acid products from bacteria. Low buffer capacity in SECC children in this research will cause the ability to adjust the plaque $\mathrm{pH}$ will also be lower. This is shown from mean salivary $\mathrm{pH}$ in SECC children was lower $(5.86 \pm 0.51)$ than in caries-free children $(7.02 \pm 0.39)$ (Table IV). This results were in accordance with Muchandi et al research in 2015 found that unstimulated salivary $\mathrm{pH}$ in SECC group was lower than in caries-free group $(\mathrm{p}<0.001)[12]$.

Saliva with low $\mathrm{pH}$ can caused loss of calcium phosphate, hydroxyl and crystal hydroxyl apatite ion. Saliva with critical acidity degree 5.5 can cause hydroxyapatite dissolution or tooth demineralization [18]. In this research, mean of salivary $\mathrm{pH}$ in SECC children almost near critical $\mathrm{pH}$ which is $5.86 \pm 0.51$, and will be one of caries risk factor that needs attention, because even before child eating carbohydrate, the salivary $\mathrm{pH}$ is low enough; different from mean of salivary $\mathrm{pH}$ in caries-free children that was in normal category (7.02 \pm 0.39$)$. In addition, salivary $\mathrm{pH}$ in SECC children mostly was very acid (pH 5-5.8) which was $56.7 \%$ and acid (pH 6-6.6) which was $40 \%$ and only 1 children had normal salivary $\mathrm{pH}(\mathrm{pH}$ 6.8-7.8), while in caries-free children mostly had normal salivary $\mathrm{pH}$ which was $86.7 \%$ and there were no children had very acid $\mathrm{pH}$ (Table III).

One ways in improving oral cavity $\mathrm{pH}$ is by reducing the acid-producing cariogenic bacteria and also regulating the carbohydrate diet of the child. Dental filling in children with SECC may reduce the number of bacteria in the oral cavity.

Researchers reported that children with SECC had higher S.mutans count than caries-free children [19,20]. Saraithong et al (2015) reported that children who consumed soft drinks at least once a day had higher S.mutans than children that never or occasionally consumed soft drinks [21]. Children consuming sugary drinks at night at least twice a day was likely to get caries $(\mathrm{OR}=2.38, \mathrm{Cl}=1.34-5.99)$ than children who never drink sweet drinks at night [22]. Eating between main meals should also be avoided, because it can kept the acidic $\mathrm{pH}$, because salivary buffer capacity does not have time to neutralize the $\mathrm{pH}$ in oral cavity [18]. Therefore, in SECC children it is recommended to do dental treatment as soon as possible and to control the carbohydrate diet.

As a conclusion, three salivary parameters (salivary flow, buffer, and $\mathrm{pH}$ ) in early childhood contributed in dental caries progression due to the salivary 
characteristic in SECC children that had lower salivary quantity and quality than caries-free children. If the child had caries then the salivary $\mathrm{pH}$ and buffer capacity will affect the demineralization activities process.

\section{ACKNOWLEDGMENT}

Acknowledgments are addressed to the Minister of Research, Technology and Higher Education of Indonesia, at the expense of this study was derived from DRPM Directorate General of Strengthening Risbang in 2017.

\section{REFERENCES}

[1] American Academy of Pediatric Dentistry (AAPD), "Policy on early childhood caries (ECC): Classifications, consequences, and preventive strategies," Refer. Man., vol. 37, pp. 50-52, 2014.

[2] A. Bissar, P. Schiller, A. Wolf, U. Niekusch, AG. Schulte, "Factor contributing to severe early childhood caries in south west Germany," Clin. Oral Investig., vol. 18, pp. 1411-1418, June 2014.

[3] R.J Schroth, S. Halchuk, L. Star, "Prevalence and risk factors of caregiver reported severe early childhood caries in Manitoba First Nations children: results from the RHS Phase 2 (20082010)," Int. J. Circump. Health, vol. 72, pp. 21167, August 2013.

[4] C.G.A. Nobile, L. Fortunato, A. Bianco, C. Pileggi, M. Pavia, "Pattern and severity of early childhood caries in Southern Italy: A preschool-based cross-sectional study," B.M.C. Pub. Health, vol. 14, pp. 206, 2014

[5] R.G. Mangla, R. Kapur, A. Dhindsa, M. Madan, "Prevalence and associated risk factors of severe early childhood caries in 12 to 36 month old children of Sirmaur district, Himachal Pradish, India," Int. J.Clin.Pediatr. Dent., vol. 10, pp. 183-187, AprilJune 2017.

[6] H.R. Priyadarshini, S.S. Hiremath, M.Puranik, S.M. Rudresh, T. Nagaratnamma," Prevalence of early childhood caries among preschool children of low socioeconomic status in Bangalore city, India," J. Int. Soc. Prev. and Commun. Dent., vol. 1, pp. 27-30, January-June 2011.

[7] K. Peltzer, A. Mongkolchati, "Severe early childhood caries and social determinants in three-year-old children from Northern Thailand: a birth cohort study," B.M.C. Oral Health, vol. 15, pp. 108, September 2015.

[8] R.W. Sutjipto, Herawati, S. Kuntari, "Prevalensi early childhood caries dan severe early childhood caries pada anak prasekolah di Gunung Anyar Surabaya," M. Kedokt. Gigi, vol. 47, pp. 186-189, 2014

[9] E. Octiara, E.A. Tamba, "Hubungan ekonomi keluarga dan pendidikan ibu dengan early childhood caries (ECC) anak usia 12-36 bulan di Kecamatan Medan Denai,” Dentika Dent. J., vol. 17 , pp. 79, July 2012.
[10] D. Jayaraj, S. Ganesan, "Salivary $\mathrm{pH}$ and buffering capacity as risk markers for early childhood caries: A clinical study", J. C.P.D, vol. 8, pp. 167-171, September-December 2015.

[11] J.M. Yoshizawa, C.A. Schafer, J.J. Schafer, J.J. Farrell, B.J. Paster, D.T.W. Wong, "Salivary biomarkers: Toward future clinical and diagnostic utilities," Clin. Microbiol., vol. 26, pp. 781-91, October 2013.

[12] S. Muchandi, H. Walimbe, M.N.A. Bijle, M. Nankar, S. Chaturvedi, P. Karekar, "Comparative evaluation and correlation of salivary $\mathrm{pH}$ in caries free and severe early childhood caries children," J. C.D.P., vol. 16, pp. 234-237, March 2013.

[13] W.M. El-kwatehy, A.R. Youssef, "Salivary biomarkers in caries affected and caries free children," Int. J. Dent. Oral Sci, vol. 3 , pp. 348-3452, October 2016.

[14] S. Kuriakose, C. Sundaresan, V. Mathai, E. Khosla, F.M.A Gaffoor, "A comparative study of salivary buffering capacity, flow rate, resting $\mathrm{pH}$, and salivary immunoglobulin $\mathrm{A}$ in children with rampant caries and caries-resistant children," J. Indian Soc. Pedo. and Prev. Dent., vol. 31, pp. 69-73, AprilJune 2013.

[15] D. Animireddy, V.T.R. Bekkem, P. Vallala, S.B. Kotha, S Ankireddy, N. Mohammad, "Evaluation of $\mathrm{pH}$, buffering capacity, viscosity and flow rate levels of saliva in caries-free, minimal caries and nursing caries children: An in vivo study,' Contemp. Clin. Dent., vol. 5, pp. 324-328, July 2014.

[16] A. Almushyt, O. El Meligi, "Salivary characterictics in a sample of preschool children with severe early childhood caries (SECC),” J. KAU Med. Sci., vol. 17, pp. 41-58, January 2010.

[17] L. Guo, W. Shi, "Salivary biomarkers for caries risk assessment," J. Calif. Dent. Assoc., vol. 41, pp. 107-118, February 2013

[18] P.D.V. de Almeida, A.M.T Gregio, M.A.N Machado, A.A.S de Lima, L.R. Azevedo, "Saliva composition and functions: A comprehensive review," J. Contemp. Dent. Pract., vol. 9, pp. 1 11, March 2008

[19] A.S. Thakur, S. Acharya, D. Singhal, N. Rewal, N. Mahajan, B Kotwal, "A comparative study of Mutans Streptococci and Lactobacilli in mothers and children with early childhood caries (ECC), severe early childhood caries (S-ECC) and caries free group in a low income population," O.H.D.M., vol. 13, pp. 1091-1095, December 2014.

[20] C.V. Hughes, M. Dahlan, E. Papadopolou, R.L. Kent Jr., C.Y Loo, N.S. Pradhan, et al., "Aciduric microbiota and mutans streptococci in severe and recurrent severe early childhood caries," Pediatr. Dent., vol. 34, pp. 16-23, March-April 2013.

[21] P. Saraithong, K. Pattanaporn, Z. Chen, S. Khongkhunthian, P. Laohapensang, N. Chhun, et al., "Streptococcus mutans and Streptococcus sobrinus colonization and caries experience in 3 and 5-year-old Thai children," Clin. Oral Investig., vol. 19, pp 1955-1964, November 2015.

[22] S. Syed, N. Nisar, N. Khan, N. Dawani, N Mubeen, Z Mehreen, "Prevalence and factors leading to early childhood caries among children (71 months of age or younger) in Karachi, Pakistan,” J.D.O.H., vol. 7, pp. 153-159, October 2015 